\title{
PANDEMIC, EXCEPTION AND THE LAW: NOTES ON THE SHATTERED NOMOS OF EUROPE
}

\begin{abstract}
In this article I propose a critical evaluation of the current European politico-legal landscape that unfolds under the conditions of the COVID-19 pandemic. My aim is to offer an analysis of the symbolic status of legality in this context and to reflect on its historical trajectory, by introducing it in a longer historical timescale than usually proposed as well as by insisting on the specific nexus between emergency legislation and authoritarian ideologies within Europe. In doing so I propose a new genealogy of the state of exception apt to articulate the relationship between the force of law, legal normativity, and ideology in modern capitalism. The thesis that I defend here is a simple one: the ongoing pandemic has operated a historical acceleration that the law, understood here as medium that articulates power symbolically in a public and ostensible manner, is not able to catch up with. To substantiate this thesis, I venture first to take stock of the existing theories, analyses and narratives on the relation between the pandemic and the politico-legal landscape of Europe. In doing so I shall focus first on traditional constitutional law accounts and on Italian philosopher Giorgio Agamben's criticism of the legal responses to the pandemic. Following this analysis, I move towards a situation of the pandemic within the sphere of the multiple crises befalling Europe that have become visible since 2015. At this stage I draw attention to the manifold layers of emergency legality and states of exception that have been sapping the liberal democratic nomos putatively defended within Europe. In a third move, I embark on a synoptical clarification of the relationship between law, ideology and the history of class struggle. In a fourth and last intervention I intend to assess the current nexus between the pandemic, exception and the law as a specific form of dissolution of the liberal nomos.
\end{abstract}

Keywords: COVID-19, pandemic, state of exception, nomos, liberalism.

\section{PANDEMIA, WYJĄTEK I PRAWO: SZKIC O ZDRUZGOTANYM NOMOSIE EUROPY}

Streszczenie. W niniejszym artykule proponuję krytyczną ocenę obecnego europejskiego krajobrazu polityczno-prawnego, który rozwija się w warunkach pandemii COVID-19. Moim celem jest zaproponowanie analizy symbolicznego statusu legalności w tym kontekście i zastanowienie się nad jej historyczną trajektorią, poprzez wprowadzenie jej w dłuższą niż zazwyczaj proponowana perspektywę historyczną, jak również poprzez podkreślenie specyficznego związku pomiędzy ustawodawstwem dotyczącym sytuacji nadzwyczajnych a ideologiami autorytarnymi w Europie.

*University of Nottingham; cosmin.cercel@nottingham.ac.uk 
Tym samym proponuję nową genealogię stanu wyjątkowego, pozwalającą na wyartykułowanie relacji między siłą prawa, normatywnością prawną i ideologią w nowoczesnym kapitalizmie. Teza, której tu bronię, jest prosta: aktualna pandemia spowodowała historyczne przyspieszenie, którego prawo, rozumiane tu jako medium symbolicznie artykułujące władzę w sposób publiczny i pozorny, nie jest w stanie dogonić. Aby uzasadnić tę tezę, najpierw dokonam bilansu istniejących teorii, analiz i narracji na temat relacji między pandemią a polityczno-prawnym krajobrazem Europy. W tym celu skupię się najpierw na tradycyjnych ujęciach prawa konstytucyjnego oraz na krytyce reakcji prawnych na pandemię dokonanej przez włoskiego filozofa Giorgio Agambena. Po tej analizie przechodzę do umiejscowienia pandemii w sferze wielorakich kryzysów dotykających Europę, które stały się widoczne od 2015 roku. Na tym etapie zwracam uwagę na różnorodne warstwy prawa dotyczącego sytuacji nadzwyczajnych i stanów wyjątkowych, które podważają liberalno-demokratyczny nomos, który jakoby jest broniony w Europie. W trzecim posunięciu podejmuję się synoptycznego wyjaśnienia relacji między prawem, ideologią i historią walki klasowej. W czwartej i ostatniej części artykułu zamierzam ocenić obecny związek między pandemią, wyjątkiem i prawem jako szczególnym przejawem rozkładu liberalnego nomosu.

Słowa kluczowe: COVID-19, pandemia, stan wyjątkowy, nomos, liberalizm.

\section{INTRODUCTION: THE IRRUPTION OF THE REAL}

In this article I propose a critical evaluation of the current European politicolegal landscape that unfolds under the conditions of the COVID-19 pandemic. My aim is to offer an analysis of the symbolic status of legality in this context and to reflect on its historical trajectory, by introducing it in a longer historical timescale than usually proposed as well as by insisting on the specific nexus between emergency legislation and authoritarian ideologies within Europe. In doing so I propose a new genealogy of the state of exception apt to articulate the relationship between the force of law, legal normativity, and ideology in modern capitalism. The thesis that I defend here is a simple one: the ongoing pandemic has operated a historical acceleration that the law, understood here as medium that articulates power symbolically in a public and ostensible manner, is not able to catch up with. Rather than acting as a cure for the particular crisis, law is continuing the process of corrosion and self-erasure of liberal regimes of legality. To substantiate this thesis, I venture first to take stock of the existing theories, analyses and narratives on the relation between the pandemic and the politico-legal landscape of Europe. In doing so I shall focus first on traditional constitutional law accounts and on Italian philosopher Giorgio Agamben's criticism of the legal responses to the pandemic. This choice, as uneven at it might appear at a first glance is useful for offering a glance into the state of the art of both established and critical approaches to the pandemic. Following this analysis, that perhaps unsurprisingly emphasises the limits of our current politico-legal imaginary, I move towards a situation of the pandemic within the sphere of the multiple crises befalling Europe that have become visible since 2015. At this stage I draw attention to the manifold layers of emergency legality and 
states of exception that have been sapping the liberal democratic nomos putatively defended within Europe. Such an evaluation opens the way to a historical and philosophical inquiry into the role of the state of exception within modern legal systems as an enabler of authoritarian regimes and ideologies. In a third move, I embark on a synoptical clarification of the relationship between law, ideology and the history of class struggle. In a fourth and last intervention I intend to assess the current nexus between the pandemic, exception and the law as a specific form of dissolution of the liberal nomos.

Before I proceed, a number of clarifications seem to be necessary. By limiting my analysis to the European context, and by discussing "European" law, I by no means intend to refer only to Union legislation, constitutional arrangements and so forth. I consider than Europe is much more than this, insofar as I also consider that law is much more than rules, commands or normative statements. What I am interested in exploring, is the shattered forms of liberal legality developed un der the promises of the rule of law and universalism of rights that have been for better or worse fostered by European states since 1945 in some places, or since the end of the last century in most of them. In a sense, Europe of this nomos, is the Europe of rights, of the European Court of Human Rights, inasmuch as is the Europe of democratic values, that have been built historically on the ruins of war, authoritarian regimes and totalitarian ideologies (Fraser 2005): it is a Europe with historical roots and a normative existence, that is formalised in constitutions, declarations of rights, Charters, Conventions, international treaties or a sui generis legal order. It is superfluous to add that I am not interested here with the positive enactments of this normative statements, as I am not interested with their place within the respective hierarchy of norms to which they belong, more than it is necessary for the purposes of this investigation. Furthermore, I am not interested in the Europe of markets and free trade and the way in which its material existence positively undermines the enactment of the democratic promises - this would be a daunting task.

What I am interested in, is the supra-national, trans-national and national clusters of legal normativity that embody a shared ideal of liberal legality that has emerged at the end of the Second World War and after the fall of authoritarian regimes. In other words, my interest lies with the nomos of our time, that is the "normative universe" that we inhabit by constantly creating "a world of right and wrong, of lawful and unlawful" (Cover 1983, 4). What I intend to follow is, the object of the ideology that has been prevalent within our polities on the continent in at least the last half of the century and which entertains both implicit and explicit lines of continuity with other historical projects since the age of Enlightenment (Skinner 2021). For the sake of clarity, I haste to name them here: separation of powers, liberal individualism, constitutionalism, procedural democracy. Yet, given that these normative statements are historically inscribed, they do entertain at least implicit connections with other spheres, be they economy or culture. In this 
sense, this investigation is avowedly interdisciplinary insofar as it takes its object as a part of a wider symbolic framework that effectively constructs our politicolegal reality.

By taking the risk of an oversimplification, the main legal and theoretical responses to the pandemic can be lumped up under a rather easy periodisation: an initial attempt to respond, somewhat hastily to the urgency of the situation, from late February until late April 2020; the fabrication of a "new normal" and a first evaluation of the situation, that lasted from late May until late October 2020, depending on country and an ongoing stage of addressing a second and a third wave of the pandemic, to which one could add as a side-thread the emergence of the vaccine blunder. The core difficulty raised by the virus from the very beginning was one of finding the right symbolic frames for approaching and experiencing it, that is to be able to articulate its impact within the existing language. As such, it can be aptly described as a traumatic irruption of the Real (Shepherdson 2008, 27; Lacan 1975) to use Lacanian jargon, insofar as it is an intrusion that disturbs the existing frameworks of understanding, from scientific discourse to the most basic forms of social interaction. There is little surprise then that the first legal responses were unclear, uncertain, or marked by a specific clumsiness: declarations of states of emergency with little or no constitutional grounding (Venice Commission 2020a) poorly written secondary legislation, sweeping powers attributed to all sorts of executive bodies with no necessary connection to the pandemic. In short, it can be described as law-induced uncertainty.

During this time most commentators on the established spectrum were particularly worried about the proliferation of emergency regimes and the limited ways in which democratic or at least judicial control could have been exercised. This continued to remain one of the mantras of the constitutional and legal commentariat throughout the pandemic (Serna de la Garza 2020). Legitimate and accurate as it might have been at that time it was uttered, and it might still be at the formal level today, this position restated a rather known and limited suspicion of lawyers towards the concrete dimension of a factual arrangements determining legal situations. The usual concerns reported in the Verfassungsblog dossier and the first collections of commentaries (Verfassungsblog 2020), revolve around the impact on fundamental rights, constitutional process and constitutional guarantees. Almost unanimously and unsurprisingly, the universal palliative able to curb executives' enthusiasm in exercising undue power, is considered to be the control of proportionality of these measures exercised either by national Courts, be they ordinary or Constitutional, or by supernational bodies (Lebret 2020). Indeed, the standard seems to be that of proportionality constantly invoked by the ECHR when dealing with infringements of human rights, and by constitutional lawyers when dealing with emergency (Gross, Ní Aoláin 2006, 283-289; Greene 2018, 208-209).

With a number of notable exceptions, the legal orthodoxy would continue to stay silent on two fundamental issues: the sticking tendency of emergency 
measures and the broader political implications of such powers asserted by state authorities. Within the minority opinion, there were indeed voices that have raised this issue in relation to the usual suspects, namely Hungary and Poland, yet they have circumvented the deeper pressure such measures would have on the broader status of legality from a transnational perspective. As the first wave of the pandemic was waning, and some of the initial responses - lockdowns, curfews - were being replaced by the "new normal", it was time for more legal clarity, and judicial reviews or constitutional ones started to flurry across the continent in order to limit the excesses of the initial responses (Venice Commission 2020b). This has given rise to a rather different re-assessment of the situation in which the governments were held in check by the judiciary. The mantra stayed unchanged, the need of finding a right balance between protecting lives and safeguarding freedoms. Yet, a slight shift could be observed surreptitiously in changing the focus towards the need for clarity and the importance of public freedoms even under the conditions of a pandemic, thus echoing to a larger extent economic considerations related to the impositions of lockdowns. After all, the new normal was about navigating within this middle-ground, between sanitary concerns, economic imperatives, and ideological creeds. The symbolic structure of the law was in place again, and the return constitutional and legal minutiae was there to reconstruct the seamless web of the law.

\section{BEYOND BIO-SECURITY: THE MATERIALITY OF IDEOLOGY}

At the antipodes, the critical legal field has been dominated by convenient re-evaluations and re-readings of biopolitics, bio-power, or bio-security: in the face of the catastrophe, Foucault of the Birth of Biopolitics (Foucault 2008) or Society Must Be Defended (Foucault 2003) was dusted and brought to new uses, while being re-read as a potential theoretical cure for the ongoing malaise (Sotiris 2020). Of a more apocalyptic tone, the hasty, unfortunate, and ultimately stubborn interventions of Giorgio Agamben (Agamben 2020, 17-20) took the front in addressing the issue of the pandemic, while both dividing the field of critical theory and putting his whole philosophical project in ambiguous light. In an astonishingly prolific series of interventions, since late February 2020, the Italian philosopher kept on reminding us the particular danger - no short of eschatological proportions - that has befallen the Western civilisation. The story was not new - indeed, the ongoing crisis came to reconstruct even as to detail the particular assemblages of power, life, law and violence that he postulated in his work (Agamben 1998). In a very specific sense, the politico-reality of the pandemic was agambenian.

But instead of moving beyond the already posited theses of the relationship between law and bare life as the instantiation - or indeed the nomos of modernity, 
and the obvious point that we are indeed living a state of exception, the Italian philosopher kept on engaging with the phenomenology of the exception that was unfolding before our eyes. Hasty as these "live" forms of philosophising were, they were marked by an insistence of the "political", "fictional", "constructed" dimension of the state of exception and its relation to biosecurity. In the stead of a traumatic encounter with the Real, our societies are simply just falling pray to their own self-devised, solipsistic, phantasms. Worse even, they are living the apex of the "biosecurity", that is the union between a "religion of salvation" and "state power, with its state of exception", which "is probably the most effective that the West has known so far" (Agamben 2020, 13). What we are traversing in the flurry of lockdowns, curfews, or "social-distancing", is "a diffusion of sanitary terror", a "technique of government that it has been experimented in its most extreme form" (Agamben 2020, 13-14). We are all, and not as a matter of political ontology, homines sacri, but we all somewhat desire to be: "once in question it is a threat to health, men seem willing to accept limitations on their freedom they never dreamed of being able to tolerate, neither during the two world wars nor under totalitarian dictatorships" (Agamben 2020, 13).

Without insisting further on the philosophical ruminations produced under the strain of the pandemic, it is easy to see how once the state of exception moved from the ontological to phenomenological, the accuracy of the analysis has become blurred, bordering solipsism, as the ultimate division between state power and bare life took place and "our society no longer believes in anything but bare life" (Agamben 2020, 25). Under such circumstances, it is the time for the outmost tyranny to emerge, under the "blood-stained sword of the monstrous Leviathan" (Agamben 2020, 35), as it is the political power sustained only on the preservation of life. Such position has rightly been read as a hasty conclusion about the nature of the crisis and of the exception. As Romanian philosopher and translator of Agamben, Alex Cistelecan noted:

[...] it is clear that political power (states, governments, international organisations) cannot burden itself totally and exclusively with the preservation of the bare life of their citizens, and this because of a very simple reason: between power and the biological life of its subjects something has entered for a long time now, that we call capital. (Cistelecan 2020, 38)

While indeed it might have never been Agamben's point to reflect on the ways in which the capital enters into play, ${ }^{1}$ and how material conditions shape the exception - once the exception moves away from being a conceptual and perhaps an ontological device towards becoming a phenomenological category that we experience - the question becomes important. In this sense, even if one

${ }^{1}$ A point can be made that Agamben does not disregard capitalism as a mode of production, insofar as he conflates it with religion, in a reading drawing on Debord's Society of Spectacle and the work of Walter Benjamin (Agamben 2016, 15-26). However, this reading eludes the historical development of capitalism. 
could retain the critical thrust of the Agambenian injunctions in keeping under scrutiny the activities of state power as well as the operation of law under the unfolding exception, the need for grounding the exception further historically becomes urgent.

Despite its traumatic appearance, the current state of exception does not take place in an ideological and historical vacuum. While at its core, one can and probably should, isolate a purely medical or sanitary focus, this has become obscure through a constant obliteration that political, socio-legal and ultimately ideological concerns have produced. While it would be tempting to be able to interpret this current exception in the original Schmittian sense, of a state of suspension of the law that is determined by the very factual situation, when a decision in a supreme sense has to be taken (Schmitt [1921], 12), the question is at least dubious. First, not only that the factual situation is anything but clear, but the possibility of articulating it properly within a meaningful narrative has become a matter of continual uncertainty - facts indeed are the battleground on which distinctions of a political intensity have emerged. Agamben's recent insistence on the constructed dimension of the pandemic, as dangerously closely to the obscure ideologies of the new far-right it is, does show indeed the limits that an idealistic interpretation of the factual situation proves. Of course, any interpretation of facts is decidedly political, and any evaluation of the facts necessary for the declaration of emergency measures is political, but this does not deal away with the materiality of the factual situation.

What obscures at the core the factual situation is not its discursive inscription, nor its socially constructed features, but precisely its connection with an apparatus of exception that has very little to do with the specificities of the pandemic. First, the existing exception is not new. It would be difficult, if not impossible to situate it historically - is it the declaration of the state of emergency or emergency legislation in a specific jurisdiction at a specific moment in time its beginning? Such a position would at least presuppose that the distinction between normal situation and the exceptional one would be a neat one. However, weeks before the pandemic was declared, Romania, my native country, witnessed a busy day of governmental activity in which no less than 19 emergency ordinances - that is pieces of legislation passed under extraordinary legislative delegation - were issued (Emergency Ordinance No. 8-27 of 4 February 2020). France, has lived under a state of emergency between 2015 and 2017 (Fusco 2020, 15-16; Cercel 2020a, 34-35) and not long before the COVID-19 crisis the government was flirting with uses of the state of emergency again (Cercel 2020a, 35), not to mention the fact that in October 2020 both security and medical emergencies came together following terrorist activity. The United States under Trump was witnessing a flurry of presidential executive orders since 2017 (Driesen 2019, 516-518). Under the formal constitutional texture of these measures laid deeper political divisions and fault lines that threatened the very existence of the rule 
of law. This might not have been part of a formalised and articulated state of emergency, siege or exception per se, but were indeed part of the generalised state of exception that has insinuated itself within European polities to the point of becoming a part of the normal functioning of the legal apparatus.

This regressive analysis could go back in time to the waves of disruption produced by the refugee crisis of 2015 and the security concerns befalling Europe at the wake of the terrorist attacks in Paris during the same year and in Brussels in 2016. Yet, perhaps unsurprisingly, these concerns, while obscuring the reality of European geopolitics, were soon to be doubled by ideological frameworks of cultural and racial superiority, as well as by ethnic retrenchments (Griffin 2017). The connivance between the legal operation of the exception and the nationalist tropes of blood and soil were out in the open in the discourses of the right: territory, population and states had to be defended if not with military might, at least with unfettered police powers and at worst with violations of European human rights law and international law. The rise of the so-called populist threat with its obvious rhetoric of blood and soil and its overt disdain for legal forms (Bugaric 2019, 395 $396)$, took place in the very path opened by the normalisation of the exception. Indeed, Agamben was right in 2003 (Agamben 2005 [2003], 4) when naming the normality of the exception, as a recurrent trope in the gestures of European postwar polities. Yet the story goes deeper in time, before the London attacks and the New York ones, which have marked the end of the "end of history." Despite the lessons that should have been learned from the experience of the interwar, post-war Europe was constantly living under the shadow of the exception: and it is not only the case of Ceaușescu's Romania (Cercel 2011) or Jaruzelski's Poland (Mańko 2020). It was equally the Federal Republic of Germany dealing swiftly with the Rotte Armee Faktion (Blumenau 2014), the United Kingdom of the "troubles" (McEvoy 2011), France of the Algerian war (Thénault 2004), and of course, Agamben's Italy of the years of lead. Whether the lessons of the interwar, when all of Europe (except for the Czechoslovakia) lived under a form of exception, was learned all too well or not at all, is less important.

The fact is that after the fall of Weimar and other liberal constitutions, after Hitler, the second World War and the Shoah, European states continued to positively undermine their own constitutional commitments - be they socialist, nationalist or liberal - and to allow the exercise of unfettered sovereign power as if nothing had happened. If indeed this is not enough to raise at all the interest of our contemporary global constitutional scholars all too occupied to study "populism", let us examine to which extent this trend and lines of continuity in constitutional theory and praxis go even further, back to the very origins to European constitutionalism. We should be perhaps more specific here and resist the Agambenian temptation of reading in (and therefore reading out the historical and ideological weight of the machinery of the exception) the unfolding of an a-historical relation between law/power and zoe (Agamben 1998, 4). Beyond this 
ahistorical appearance or frontispiece (Agamben 2015, 48-49) of the exception lies a material constitutional history whose meaning is still to be uncovered. If indeed the regimes of emergency and exception across Europe looked so familiar and similar (with the notable exception of the always different common law tradition) it is less because they were inscribing the unarticulated life in the mechanisms of the state (and indeed isn't it what all modern states do?), but more because their legislation can be traced back to either the mechanisms of the state of siege put in place during the French revolution (and transported by the Napoleonic armies together with ideas of codification), or by the mechanisms of the liberal interregnum of 1848 (Carver 2004).

\section{EXCEPTION: THE SHATTERED NOMOS OF EUROPE}

Looked through these lenses, the exception has a very specific role and function. The similarity is indeed material, not only in the choice of language, words, or concepts, but in the practice and aims of this institution which played a crucial role in the symbolic construction of legality through the last century. At its core lie indeed the same tropes of protection of the country against a threat, which functions as an effective prohibition and exclusion of the civil war and in praxis against its social instantiation, class struggle. Marx's analysis of the convoluted history of the 1848 revolution and its aftermath in France (Marx 1978 [1850]; Marx 1979 [1852]) is edifying in this sense by capturing the socio-political core of what was to become the recurrent drama of what we could loosely term the bourgeois nomos: faced with the rise of the proletariat, the bourgeoisie opens the way to militarism through the mechanism of dictatorship and exception. Once these become a constant presence in the politico-legal landscape and indeed part of the constitutional framework, the gate is open to authoritarianism and authoritarian slips from the constitutional sphere. Napoleon the nephew, is called to power. As Marx wrote,

The forefathers of the respectable republicans had sent their symbol, the tricolor, on a tour around Europe. They themselves in turn produced an invention that of itself made its way over the whole Continent, but returned to France with ever renewed love until it has now become naturalized in half her departments - the state of siege. A splendid invention, periodically employed in every ensuing crisis in the course of the French Revolution. But barrack and bivouac, which were thus periodically laid on French society's head to compress its brain and render it quiet; saber and musket, which were periodically allowed to act as judges and administrators, as guardians and censors, to play policeman and do night watchman's duty; mustache and uniform, which were periodically trumpeted forth as the highest wisdom of society and as its rector - were not barrack and bivouac, saber and musket, mustache and uniform finally bound to hit upon the idea of instead saving society once and for all by proclaiming their own regime as the highest and freeing civil society completely from the trouble of governing itself. (Marx 1979 [1852], 118) 
We should note from this flowery description the process through which the state of siege - an invention of the French revolution - returned half a century later in the days of the proletarian July uprising and paved the way to the abuses of the constitution perpetrated by President Louis Napoléon Bonaparte, who stormed the National Assembly (and not the Capitol) and proclaimed himself Emperor. But beyond the literary ornaments and historical detail mustered here by Marx, it is at least serviceable to consider the choice of words: the state of siege is an invention, a technology of power, which in terms of content would travel until the margins of Europe. It is part of a development through which the state was further centralised both in form and material force, by doing away with "the motley patterns of conflicting medieval plenary powers into the regulated plan of a state authority whose work is divided and centralized as in a factory" (Marx 1979 [1852], 185). As such, it is an invention which goes hand in hand with the rationalisation processes specific to constitutionalism. Albeit lurking behind the promises of formal equality and progress, the threat of the barracks and the bivouac, is part of the same machinery and was to be deployed strategically in the control of illegalisms thus assuring the law and order within the newly born bourgeois societies. However, its deployment always bore the risk of a fall or an abuse.

The irony is that even in the processes of constituting and consolidating its political power, the bourgeoisie was understanding it and indeed relating to its own power as if to a commodity. Here bourgeoisie should not be understood in a simply economic, reductive manner, but precisely as a class to which we owe the construction of modernity, based indeed of exploitation, but also adorned with culture, institutional frameworks and humanist ideals. It is a class which built the now yearned European civilisation, in a constant hesitation between barracks, bivouac and the letter of the law and through a constant blurring between the two. And who just like the Faustian apprentice sorcerer, released each time with its terrible inventions, forces which were seemingly unbeknownst. After the revolutions of 1918 and the exceptions emerging in Europe from Germany (Stolleis 1998; Kivotidis 2020; Lavis 2020) to Italy (Skinner 2013) and to Romania (Cercel 2020b; Cercel 2013) emerge the black shirts, the green shirts, the freikorps and so on. After the article 48, follows the Enabling Act, just as after the state of siege follows overt dictatorship. If we look at the written texts of the constitutions through these lenses, as cultural products and artifacts situated at the interface between sovereign power and legality and guiding the strategic deployment of legality or the use of unfettered force, we are able to read them as what they are in the height of capitalism.

Walter Benjamin's analysis of the forms of art in the capital of the $19^{\text {th }}$ century that Paris was, is extremely useful here: "With the upheaval of the market economy, we begin to recognize the monuments of the bourgeoisie as ruins even before they have crumbled" (Benjamin 1999 [1935], 13). There is a part of the 
constitutional arrangements of our past and present society which continues to be monumental, in both its grandiose promises and its legal rational minutiae. Yet, in its very texture it is sapped and supported by the threat of the barracks and bivouac, by the bayonets turned against the people. The point to be made by this archaeological excursus is perhaps less sweeping that it might seem: the state of exception that we know in modern history is that of a constant threat of unlimited power materialised in military, para-military or police repression supported by an administrative and legal apparatus able to distinguish between legal subjects and threats to the constitutional order. It is a mechanism built on the protection of the territory and population, constantly distinguishing between what (and who) should be protected and what (or who) should not. In its history of instantiations, it has been more often than not an epitome of the blood-stained sword of the monstrous Leviathan rather than the protective sword of justice. And yet this is precisely the point of the confusion we live in. Beyond the historically built frameworks through which the law and legal communities read the current exception, which are constitutive of the state of exception and continue to be since its entry in legal dogmatics and state practices, there lies the material reality of a pandemic.

The confusion is twofold: on one hand it obfuscates the uncertain level of our historical regime of legality by creating retrospectively a 'normal' situation to which one would strive to return, while on the other hand it amalgamates the political level of the exception with what would otherwise be measures of medical concern. Of course, we all know the history of the connivence between the ideological and repressive apparatuses of the state and the sphere of medicine (Lifton 1986; Foucault [1976], 217-222; Agamben 1998, 144-153), social hygiene and eugenics (Turda 2015; Turda 2010). We know to which extent, the development of new technologies and the expansion of knowledge, the emergence of a new épistémè, were functioning hand in hand with and as devices of power. But I think that one should be more specific and insist on the distinction that one ought to be able to make between what any modern polity would do in order to protect its citizens, what our polities have been historically doing, and what they actually do. I do not negate that these normative, factual, and historical questions are indeed closely connected, but pseudo-concepts, ideological and narrative tropes such as "sanitary dictatorship", "sanitary terror" professed either in the shadow of Agamben or within the ranks of the right, the libertarian circles and alike, insistently keep on conflating these levels in one Orwellian eschatological vision of a totalitarian denouement in which attempts at protecting lives are taken for necropolitical enterprises.

But indeed, isn't this position fundamentally the other side of the same dialectical coin of the discourse of the rational centre with its unfathomable and unshakable belief in the rationality of the legal machinery (COVID or not COVID we are doing pretty well considering the circumstances)? On one side the purportedly radical, foundational adherence to the "authentic" natural law, 
freedoms, and rights supported by either social Darwinist tropes or a foreclosure of the Real (Shepherdson 2008, 124), while on the other side the seemingly measured legal restrain, mimicking the seriousness and rationality of the legal discourse, while the very substance is disintegrating before our very eyes. To put it otherwise, on one side the longing for an unalienated, purportedly "real" legality and constitutionality that is yet to come or has to be brought back, while on the other the mire of the "business as usual." That both positions are false is not the main point that detains me here. What I think it is useful to recall in this mutual para-noia, is the shared conviction in the performative force of law, as if the pandemic can be tackled by decree or by democratic consensus. Displacing the problem within the frames of the law of which we are not actually aware of is of little help. On the contrary, it prevents us from seeing the social dynamics at stake. Faced with the radical alterity of the virus, we cling on reconstructing the threat within the frameworks of the exception, thus obfuscating the political choices that are within our reach as societies. State, territory, population, economy and markets all of a sudden become natural categories in the dream-like reality of the legal form. They have to be saved and protected and the choices are turned into rational ones between competing values.

\section{CONCLUSIONS}

Rather than increasing to the outmost the presumably overwhelming state-power, the virus has just displayed its impotence - the Leviathan is just an artificial empty machinery that is no longer able to produce its reproduction without demanding more sacrifice from those it pushes out of its borders. Let us recall here the trivial detail that on Hobbes' frontispiece of the Leviathan the Sovereign is floating, that is can always change and determine who is under its power/protection. And indeed, the "political" state of exception continues within the pandemic, it is not determined by it, but it is the device able to protect this very floating power of the sovereign. Under its operation, there are the formal constituents of the sovereign that are protected and not the "real" subjects of our constitutions, international conventions, and charters. For their part, they are left either to err in the "new normal" as actual homines sacri caught in between state borders, work regulations, immigration status and subjected as precisely bare life that no state power wants or can protect anymore. Consider the refugees in the Mediterranean, or in the Alps, the shipping crews stuck in never-ending quarantines, the East European seasonal workers, and the countless subjects that support the material infrastructure of our polities. Subjects to the prerogative states that our "respectable republicans" have built in the last century of national or transnational constitutionalism, their - and we should not forget that this is a malleable category - only legal protection is that of the necessity that 
the pandemic has created. It is on and against them that the politico-legal machinery of the exception is working through the ideological apparatuses calling for a return of blood and soil.

\section{BIBLIOGRAPHY}

Agamben, Giorgio. 1998. Homo Sacer: Sovereign Power and Bare Life. Translated by Daniel Heller-Roazen. Stanford CA: Stanford University Press.

Agamben, Giorgio. 2005 [2003]. State of Exception. Chicago: University of Chicago Press. https:// doi.org/10.2307/j.ctv1134d6w.16

Agamben, Giorgio. 2015. Stasis. Civil War as a Political Paradigm. Translated by Nicolas Heron. Edinburgh: Edinburgh University Press.

Agamben, Giorgio. 2016. "Capitalism as Religion.” In Agamben and Radical Politics. Edited by Daniel McLaughlin. Translated by Nicolas Heron. Edinburgh: Edinburgh University Press. https://doi.org/10.3366/edinburgh/9781474402637.003.0001

Agamben, Giorgio. 2020. A che punto siamo? L'epidemia come politica. Macerata: Quodlibet.

Benjamin, Walter. 1999 [1935]. The Arcades Project. Translated by Howard Eiland, Kevin McLaughlin. Cambridge MA: Harvard University Press.

Blumenau, Bernhard. 2014. The United Nations and Terrorism: Germany, Multilateralism, and Antiterrorism Efforts in the 1970s. Basingstoke: Palgrave Macmillan. https://doi. org/10.1057/9781137391988_7

Bugarič, Bojan. 2019. "Two Faces of Populism: Between authoritarian and democratic populism." German Law Journal 20: 390-400. https://doi.org/10.1017/glj.2019.20

Carver, Terrell. 2004. "Marx's Eighteenth Brumaire of Louis Bonaparte: Democracy, Dictatorship, and the Politics of Class Struggle." In Dictatorship in History and Theory. 103-129. Edited by Peter Baehr and Melvin Richter. Cambridge: Cambridge University Press. https://doi. org/10.1017/CBO9781139052429.006

Cercel, Cosmin. 2011. "Narrating Dystopia. Nicolae Ceaușescu's Legal Career." Journal of Comparative Law 6(2): 1-22.

Cercel, Cosmin. 2013. "The 'Right' Side of the Law. State of Siege and the Rise of Fascism in Interwar Romania." Fascism: Journal of Comparative Fascist Studies 2: 205-233. https://doi. org/10.1163/22116257-00202006

Cercel, Cosmin. 2020a. "Through a Glass, Darkly: Law, History and the Frontispiece of Exception." In States of exception: law, history, theory. 35-40. Edited by Cosmin Cercel, Gian Giacomo Fusco, Simon Lavis. Abingdon: Routledge. https://doi.org/10.4324/9780429022296

Cercel, Cosmin. 2020b. "Reversing Liberal Legality: Romania's Path to Dictatorship, 1930-1938." Journal of Romanian Studies 2(2): 23-52.

Cistelecan Alex. 2020. "Evidențe pripite." Vatra 10: 37-38.

Cover, Robert. 1983. "The Supreme Court, 1982 Term - Foreword: Nomos and Narrative.” Harvard Law Review 97: 4-68. https://doi.org/10.2307/1340787

Driesen, David M. 2019. "President Trump's Executive Orders and the Rule of Law." University of Misouri-Kansas Law Review 87: 489-524.

Foucault, Michel. 1976. Histoire de la sexualité. Vol. 1. La volonté de savoir. Paris: Gallimard.

Foucault, Michel. 2003. Society Must Be Defended. New York: Picador.

Foucault, Michel. 2008. The Birth of Biopolitics Lectures at the Collège de France, 1978-1979. Basingstoke: Palgrave Macmillan. 
Fraser, David. 2005. Law after Auschwitz: Towards a Jurisprudence of the Holocaust. Durham NC: Carolina Academic Press.

Greene, Alan. 2018. Permanent States of Emergency and the Rule of Law: Constitutions in an Age of Crisis. London: Hart.

Griffin, Roger. 2017. "Interregnum or End Game? The Radical Right in the 'post-fascist' era." In The Populist Radical Right: A Reader. 5-21. Edited by Cas Mudde. Abingdon: Routledge.

Gross, Oren. Fionnuala Ní Aolain. 2006. Law in Times of Crisis: Emergency Powers in Theory and Practice. Cambridge: Cambridge University Press. https://doi.org/10.1017/ CBO9780511493997

Kivotidis, Dimitrios. 2020. "Norm and Exception: From the Weimar Republic to the Nazi State Form." In States of exception: law, history, theory. 119-139. Edited by Cosmin Cercel, Gian Giacomo Fusco, Simon Lavis. Abingdon: Routledge. https://doi.org/10.4324/9780429022296-6 Lacan, Jacques. 1975. Le séminaire. Livre XX. Encore. Paris: Le Seuil.

Lavis, Simon. 2020. "The Exception of the Norm in the Third Reich: (Re)Reading the Nazi Constitutional State of Exception." In States of exception: law, history, theory. 92-116. Edited by Cosmin Cercel, Gian Giacomo Fusco, Simon Lavis. Abingdon: Routledge. https://doi. org/10.4324/9780429022296-5

Lebret, Audrey. 2020. "COVID-19 pandemic and derogation to human rights." Journal of Law and the Biosciences 7: 1-15. https://doi.org/10.1093/jlb/lsaa015

Lifton, Robert J. 1986. The Nazi Doctors: Medical Killing and the Psychology of Genocide. New York: Basic Books.

Mańko, Rafał. 2020. “Our Fatherland has found itself on the verge of an abyss'. Poland's 1981 martial law, or the unexpected appearance of the state of exception under actually existing socialism." In States of exception: law, history, theory. 140-166. Edited by Cosmin Cercel, Gian Giacomo Fusco, Simon Lavis. Abingdon: Routledge. https://doi.org/10.4324/9780429022296-7

Marx, Karl. 1978 [1850]. “The Class Struggles in France.” In Collected Works. Vol. 10. Karl Marx. Frederick Engels. 45-146. New York: International Publishers.

Marx, Karl. Frederick Engels. 1979 [1852]. "The Eighteenth Brumaire of Louis Bonaparte." In Collected Works. Vol. 11. 99-197. London: Lawrence \& Wishart.

McEvoy, Kieran. 2011. "What Did the Lawyers Do During the 'War'? Neutrality, Conflict and the Culture of Quietism." Modern Law Review 74(3): 350-384. https://doi.org/10.1111/j.14682230.2011.00851.x

Schmitt, Carl. 2005 [1921]. Political Theology. Four Chapter on the Concept of Sovereignty. Translated by George Schwab. Chicago: The University of Chicago Press. https://doi. org/10.7208/chicago/9780226738901.001.0001

Serna de la Garza, José Ma. 2020. COVID-19 and Constitutional Law. Ciudad de México: Universitad Autonoma de México.

Shepherdson, Charles. 2008. Lacan and the Limits of Language. New York: Fordham University Press. https://doi.org/10.5422/fso/9780823227662.001.0001

Skinner, Stephen. 2013. "Violence in Fascist Criminal Law Discourse: War, Repression and AntiDemocracy." International Journal for the Semiotics of Law 26(2): 439-458. https://doi. org/10.1007/s11196-012-9296-3

Skinner, Stephen. 2021. [Forthcoming]. "Identifying Dangers to Democracy: Fascism, the Rule of Law and the Relevance of History." In Judicial Independence in Times of Crisis. Edited by Dimitrios Giannoulopoulos, Yvonne McDermott. London: British Academy.

Sotiris, Panagiotios. 2020. “Against Agamben: Is a Democratic Biopolitics Possible?” Critical Legal Thinking, March 14, 2020. https://criticallegalthinking.com/2020/03/14/against-agamben-isa-democratic-biopolitics-possible/ [Accessed: 17 June 2021].

Stolleis, Michael. 1998. The Law under the Swastika. Chicago: University of Chicago Press. 
Thénault, Sylvie. 2004. Une drôle de justice: Les magistrats dans la guerre d'Algérie. Paris: La Découverte. https://doi.org/10.3917/dec.then.2004.01

Turda, Marius. 2010. Modernism and eugenics. Basingstoke: Palgrave Macmillan. https://doi. org/10.1057/9780230281332

Turda, Marius. 2015. The History of Eugenics in East-Central Europe: 1900-1945. London: Bloomsbury. https://doi.org/10.5040/9781474219464

Venice Commission. 2020a. Observatory of emergency situations: Was a state of emergency declared in your country due to the COVID-19 pandemic? By what authority and for how long? https://www.venice.coe.int/files/EmergencyPowersObservatory//T06-E.htm [Accessed: 17 June 2021].

Venice Commission. 2020b. Observatory of emergency situations: was this additional legislation subject to judicial review? https://www.venice.coe.int/files/EmergencyPowersObservatory// T16-E.htm [Accessed: 17 June 2021].

Verfassunsgblog. 2020. COVID-19 and States of Emergency. Debate. https://verfassungsblog.de/ category/debates/covid-19-and-states-of-emergency-debates/ [Accessed: 17 June 2021].

\section{Legal Acts}

Emergency Ordinance No. 8-27 of 4 February 2020. In Monitorul Oficial No. 89. 6 February 2020. 